\title{
Studies on Phylogeny of Chaetomium Species of India
}

\author{
V. Chandra Sekhar*, T. Prameeladevi, Deeba Kamil and Dama Ram
}

Division of Plant Pathology, Indian Agricultural Research Institute, New Delhi-110012, India

*Corresponding author

\section{A B S T R A C T}

\begin{tabular}{l} 
K e y w or d s \\
$\begin{array}{l}\text { Chaetomium, Molecular } \\
\text { species identification, ITS } \\
\text { (internal transcribed } \\
\text { spacer), Phylogeny }\end{array}$ \\
Article Info \\
\hline $\begin{array}{l}\text { Accepted: } \\
\text { 17 July } 2018 \\
\text { Available Online: } \\
\text { 10 August } 2018\end{array}$ \\
\hline
\end{tabular}

\section{Introduction}

Chaetomium is a fungus can be exploited economically and commercially. This fungus is extensively used in degradation of cellulolytic material (Umikalsom et al., 1997 $\&$ 1998). In the field of Agriculture this organism has been employed as a biocontrol for reducing the disease incidence against several plant pathogens (Soytong et al., 2001, Aggarwal et al., 2004, Dhingra, et al., 2003). This fungus has wide distribution having more than 160 recognized species (Wang et al., 2014). In India alone reports have been suggested that more than 60 species (http:// www.indiabiodiversity.org/species/) were occurring. The contemporary species concept for this fungus includes a broadly defined morphological diversity as well as a large number of synonymies with limited phylogenetic evidence (Wang et al., 2016). Thus it is necessary to find an alternative method for accurate identification of the species and grouping of this genus. The advent of molecular tools for investigations in fungal identification has paved better way for easier and more accurate identification. Furthermore very limited knowledge is known for molecular identification for this fungus (Asgari and Zare, 2011, Sharma et al., 2013). Thus an attempt has been made to identify species and accurate grouping for different species of Chaetomium based on molecular sequencing data of Chaetomium. 


\section{Materials and Methods}

Collection, molecular identification and characterization of Chaetomium species

The investigation was started with collecting different samples from different parts of Delhi- NCR region. And the samples were isolated and identified based on basic generic character of Chaetomium. The details of the isolates collected was mentioned in the Table 1.Total forty four samples were confirmed as Chaetomium and were used for the present investigation. The main objective of the investigation was to construct the phylogenetic trees to differentiate Chaetomium species. For this purpose six gene regions were considered viz., ITS, tef- 1 , $r p b 2$ and $\beta$-tubulin, actin and calmodulin (Santamaria et al., 2009). Initially molecular identification and characterization was carried out by amplification and sequencing of ITS region. Subsequently multigene phylogeny was undertaken to know the best region for grouping of species by using above said six regions.

Molecular characterization of collected isolates of Chaetomium species using ITS region

\section{DNA extraction}

Genomic DNA was extracted from all the forty four isolates of Chaetomium using monosporic cultures by CTAB (Cetyltrimethyl Ammonium Bromide) method (Culling, 1992). $0.2 \mathrm{~g}$ of mycelium mat of seven days old was collected from potato dextrose broth and grounded in sterilized pestle and mortar using liquid nitrogen and transferred to $1.5 \mathrm{ml}$ eppendorf micro tubes. $600 \mu \mathrm{l}$ of preheated $\left(60^{\circ} \mathrm{C}\right) 2 \times \mathrm{CTAB}$ extraction buffer $(2 \%(\mathrm{w} / \mathrm{v})$ CTAB, $100 \mathrm{mM}$ Tris-HCl, $1.4 \mathrm{M} \mathrm{NaCl}, 20$ $\mathrm{mM}$ EDTA, $\mathrm{pH}$ 8.0) was added to the eppendorf micro tubes. The solution was incubated at $60^{\circ} \mathrm{C}$ for one hour in water-bath with occasional gentle stirring. To this solution an equal volume of chloroform and isoamyl alcohol (24:1) was added and mixed thoroughly. The mixture was subsequently centrifuged at $10,000 \mathrm{rpm}$ for $20 \mathrm{~min}$ at $24^{\circ} \mathrm{C}$. Aqueous phase was separated and transferred to a fresh tube. To this aqueous phase an equal volume of chloroform and isoamyl alcohol (24:1) was added and mixed thoroughly and centrifuged at $10,000 \mathrm{rpm}$ for $20 \mathrm{~min}$ at $24^{\circ} \mathrm{C}$. These steps were repeated 2- 3 times till a clear aqueous phase was obtained. To this clear aqueous phase 0.6 volume of ice cold isopropanol and 0.1 volume of sodium acetate buffer $(3 \mathrm{M})$ was added and incubated at $-20^{\circ} \mathrm{C}$ for 30 minutes. DNA was precipitated by centrifuging at $10,000 \mathrm{rpm}$ for $10 \mathrm{~min}$ at $4^{\circ} \mathrm{C}$. The precipitate was treated with $75 \%$ ethanol and centrifuged at 10,000 rpm for 10 $\min$ at $4^{\circ} \mathrm{C}$. Aqueous phase was discarded and DNA was dried under a regular air flow for 20 min, re-suspended in $70 \mu \mathrm{TE}$ buffer and stored at $-20^{\circ} \mathrm{C}$. The presence of DNA in the samples was further confirmed by separating them on $0.8 \%$ agarose gel at 80 volts for 45 min using gel electrophoresis unit. The concentration of DNA was measured through spectrophotometrically using Nano drop 2000 spectrophotometer.

\section{PCR amplification using internal transcribed spacer (ITS)}

The molecular identification of the purified isolates was done by using with the sequencing of the internal transcribed spacer (ITS) sequences. The amplification of ITS region was carried out using universal primers ITS1 (5'-TCCGTAGGTGAACCTGCGG-3') and ITS4 (5'-TCCTCCGCTTATTGAT ATGC-3') (White et al., 1990). The DNA fragment consisting of $3^{\prime}$ end of the $18 \mathrm{~S}$ rDNA, ITS1, the 5.8 rDNA, ITS2 and the 5' end of the 28S rDNA was amplified using ITS1 and ITS4 primers. PCR reactions were 
carried out in $0.2 \mathrm{ml}$ thin walled PCR tubes with a total reaction volume of $25 \mu 1$ containing $12.5 \mu \mathrm{l}$ of Dream Taq (2X) of ThermoScientific make (master mix consisting of buffer, dNTP's, $\mathrm{MgCl}_{2}, \quad$ Taq DNA polymerase at appropriate concentrations and pre mix of loading dye), $1 \mu \mathrm{l}(10 \mathrm{Pmol} / \mu \mathrm{l})$ of each forward and reverse primers, $1 \mu \mathrm{l}(100$ ng/ $\mu \mathrm{l})$ of DNA sample and nuclease free water. The PCR amplification conditions were initial denaturation at $94^{\circ} \mathrm{C}$ for $5 \mathrm{~min}, 35$ cycles of denaturation at $94^{\circ} \mathrm{C}$ for $1 \mathrm{~min}$, primer annealing at $55^{\circ} \mathrm{C}$ for $1 \mathrm{~min}$, primer extension at $72^{\circ} \mathrm{C}$ for $2 \mathrm{~min}$, followed by final primer extension at $72^{\circ} \mathrm{C}$ for $5 \mathrm{~min}$.

\section{Sequencing of the amplified ITS fragments}

The amplified products were separated on $1.2 \%$ agarose gel at 80 volts for $45 \mathrm{~min}$ using $1 \mathrm{x}$ TAE buffer ( $\mathrm{pH}$ 8.0) containing ethidium bromide. The gels were photographed using gel documentation system. Amplicons of 500 to $650 \mathrm{bp}$ were selected for sequencing the ITS region. For size selection a co-resolved $100 \mathrm{bp}$ ladder was used. Sequencing of all the samples with distinct band was done through Eurofins Scientific, Bangalore.

\section{Identification of Chaetomium species through ITS sequences}

Molecular identification of Chaetomium spp. was done using nucleotide sequences of ITS region through NCBI (National Centre for Biotechnology Information) BLAST (Basic Local Alignment Search Tool) (webpage: http://blast.ncbi.nlm.nih.gov) and the sequences were submitted to NCBI Genbank.

Multigene (actin, $\beta$-tubulin, calmodulin, $r p b 2$ and $t e f-1)$ phylogeny of the isolates of Chaetomium spp.

The Chaetomium DNA isolated earlier for ITS amplification was used for the PCR amplification of the above genes.
PCR amplification of actin, $\beta$-tubulin, calmodulin, rpb2 and tef-1 genes

The genes (actin, $\beta$-tubulin, calmodulin, $r p b 2$ and tef-1) regions were amplified using the primers given in Table 2 .

Sequencing of the amplified actin, $\beta$ tubulin, calmodulin, rpb2and tef-1 fragments

The amplified products of actin, $\beta$-tubulin, calmodulin, $r p b 2$ and tef-lgene regions were separated on $1.2 \%$ agarose gel containing ethidium bromide at 80 volts for $45 \mathrm{~min}$ using 1x TAE buffer with $\mathrm{pH}$ 8.0. The amplified fragments of DNA were compared with ladder of $100 \mathrm{bp}$. The gels were photographed using gel documentation system. Sequencing of all the above regions of the samples with distinct band was done through Eurofins Scientific, Bangalore.

\section{Phylogenetic analysis}

Multiple sequence alignment of the above regions along with ITS region was performed using the Clustal W algorithm of MEGA 6.0 software. Phylogenetic tree was constructed using maximum parsimony (MP) analysis. Confidence values were assessed from 1000 bootstrap replicates of the original data.

\section{Results and Discussion}

Molecular identification and phylogenetic analysis of Chaetomium species

\section{Molecular identification of Chaetomium isolates based on ITS region}

PCR amplification of all the forty four isolates of Chaetomium was done using the primers ITS1 and ITS4. ITS is a conserved rDNA sequence that has been widely used both alone and in combination with other universal sequences, such as $\beta$-tubulin, actin, etc., to 
identify, characterize, and to perform phylogenetic analysis of fungal isolates (Balazy et al., 2008). The sequence length of ITS region was found to be 500-650bp (Approx.) (Fig. 1). Molecular identification of Chaetomium spp. using ITS region sequences was done through NCBI BLAST (webpage: http://blast.ncbi.nlm.nih.gov) for the species identification. The identification percentage was found to be $96-100 \%$. The ITS sequences were submitted to NCBI and accession numbers were acquired (Table 3 ).

\section{Multigene phylogenetic analysis}

The identification of Chaetomium species confirmed through the molecular sequences of ITS region were used for further analysis. To perform multigene phylogenetic analysis, five regions were considered viz., actin, $\beta$-tubulin. calmodulin, $r p b 2$ and tef-1along with ITS region.

PCR amplification of actin, $\beta$-tubulin. calmodulin, rpb2 and tef-lwas done using respective primers as shown in Table 2.The amplified products were separated and sequenced. An approximate length of $250 \mathrm{bp}$ (Fig. 2), 500 bp (Fig. 4), 900 bp (Fig.6), 1050 bp (Fig.8) and $250 \mathrm{bp}$ (Fig.10) of actin, $\beta$ tubulin, calmodulin, rpb2 and tef-1 respectively were obtained.

Only 23 isolates showed amplification of calmodulin gene. All the forward reaction sequenced data were used for the five regions of 44 samples along with ITS to construct dendrogram and evolutionary analyses.

The maximum parsimony tree was obtained using the subtree-pruning-regrafting (SPR) algorithm (Nei and Kumar, 2000). The percentage of replicate trees in which the associated taxa clustered together in the bootstrap test (1000 replicates) was shown next to the branches (Felsenstein, 1985).

\section{Phylogenetic analysis of Actin region}

It was evident from the dendrogram (Fig.3) that the different species of Chaetomium grouped into six major clusters. Two isolates of $C$. perluicdum (C-73 and C-81), six isolates of $C$. atrobrunneum (C-68, C-19, C-61, C-03, C-18 and C-20) and eight isolates of $C$. megalocarpum (C-48, C-22, C-21, C-23, C70, C-65, C-77 and C-66) made into different Clusters (Clusters 3, 4 and 6). C. brasiliense isolates (C-07, C-45, C-50, C-46 and C-76) grouped in Cluster 1 along with one isolate of C. nigricolor (C-55). Three isolates of $C$. globosum viz., C-42, C-62 and C-15 grouped with $C$. funicola isolates (C-12, C-16, C-80, and $\mathrm{C}-17$ ) in Cluster 2. Most heterogeneous grouping was observed in Cluster 5 wherein 12 isolates of C. globosum (C-51, C-08, C-10, C-57, C-59, C-60, C-05, C-74, C-11, C-72, C40 and C-58) were grouped with one isolate of C.elatum (C-02), one isolate of $C$. atrobrunneum (C-78) and one isolate of $C$. funicola (C-47).

The grouping of Chaetomium species was good in Clusters 3, 4 and 6 using actin sequences but in the remaining clusters it appeared either totally or partially hetereogenous grouping.

\section{Phylogenetic analysis of $\beta$-tubulin region}

The dendrogram (Fig.5) showed that the different species of Chaetomium were grouped into six clusters. The isolates (C-70, C-77, C65, C-66, C-21, C-22 and C-23) of $C$. megalocarpum were grouped in Cluster 1 yet one isolate (C-48) of this species grouped with other species of Chaetomium in cluster 4 . In cluster 2 the isolates (C-51, C-08, C-10, C-05, $\mathrm{C}-42, \mathrm{C}-72, \mathrm{C}-59, \mathrm{C}-11$ and C-57) of $C$. globosum grouped with one isolate (C-02) of $C$. elatum and one isolate (C-07) of $C$. brasiliense. In cluster 3 all the isolates $(\mathrm{C}-12$, C-80, C-16, C- 47 and C-17) of C. funicola 
grouped with two isolates of $C$. globosum viz., $\mathrm{C}-15$ and C-40. Most heterogeneous grouping was observed in the cluster 4 in which four isolates (C-74, C-60, C-58 and C-62) of C.globosum were present with one isolate of each $C$. megalocarpum (C-48), $C$. atrobrunneum (C-68), C. brasiliense (C-45) and $C$. nigricolor $(\mathrm{C}-55)$.

In Cluster 5 six isolates of $C$. atrobrunneum (C-78, C-03, C-20, C-18, C-19 and C-61) two isolates of $C$. perlucidum (C-81 and C-73) and one isolate of $C$. brasiliense (C-76) grouped together. Cluster 6 was the smallest one with two isolates of $C$. brasiliense (C-46 and C-50). Even though, the isolates of Chaetomium were not grouped in homogenous manner, interspecific diversity was higher in comparison to intraspecific diversity.

\section{Phylogenetic analysis of Calmodulin region}

Heterogeneous grouping was observed for the Chaetomium species using the calmodulin sequences. All the species were grouped into three major clusters (Fig 7). In Cluster 1, $C$. globosum isolates (C-40, C-10, C-51 and C05) grouped with two isolates (C-50 and $\mathrm{C}-07$ ) of $C$. brasiliense and one isolate (C-02) of $C$. elatum. In Cluster 2, four isolates viz., C-22, C-70, C-77 and C-23 of C. megalocarpum grouped with two isolates $(\mathrm{C}-68$ and $\mathrm{C}-78)$ of C. atrobrunneum and one isolate (C-55) of $C$. nigricolor and in Cluster 3 , two isolates of each C. globosum (C-08 and C-72), $C$. megalocarpum (C-21 and C-48), $C$. brasiliense (C-76 and $\mathrm{C}-46)$ and $C$. atrobrunneum (C-19 and $\mathrm{C}-18)$ and one isolate of $C$. funicola (C-80) grouped together.

\begin{tabular}{|c|c|c|c|}
\hline SI No & Isolate & Source & Place of Collection \\
\hline 1 & $\mathrm{C}-02$ & Soil & New Delhi \\
\hline 2 & $\mathrm{C}-03$ & Soil & New Delhi \\
\hline 3 & $\mathrm{C}-05$ & Soil & New Delhi \\
\hline 4 & C-07 & Soil & New Delhi \\
\hline 5 & $\mathrm{C}-08$ & Soil & New Delhi \\
\hline 6 & $\mathrm{C}-10$ & Soil & New Delhi \\
\hline 7 & $\mathrm{C}-11$ & Soil & New Delhi \\
\hline 8 & $\mathrm{C}-12$ & Soil & New Delhi \\
\hline 9 & $C-15$ & Chilli seed & New Delhi \\
\hline 10 & $\mathrm{C}-16$ & Mushroom Compost & New Delhi \\
\hline 11 & $\mathrm{C}-17$ & Dried Cow Dung & New Delhi \\
\hline 12 & $\mathrm{C}-18$ & Bottle brush tree leaf & New Delhi \\
\hline 13 & $\mathrm{C}-19$ & Soybean seeds & New Delhi \\
\hline 14 & $C-20$ & Paper & New Delhi \\
\hline 15 & $\mathrm{C}-21$ & Neem bark & New Delhi \\
\hline 16 & $\mathrm{C}-22$ & Soil & Gurgoan \\
\hline 17 & $C-23$ & Soil & Gurgoan \\
\hline 18 & C- 40 & Soil & Noida \\
\hline 19 & $\mathrm{C}-42$ & Mushroom compost & Noida \\
\hline 20 & $\mathrm{C}-45$ & Soil & Rohthak \\
\hline 21 & $\mathrm{C}-46$ & Soil & Rohthak \\
\hline 22 & $\mathrm{C}-47$ & Soil & Rohthak \\
\hline 23 & C-48 & Wheat grain & Rohthak \\
\hline 24 & C- 50 & Soil & Hansi \\
\hline 25 & $C-51$ & Mushroom compost & Hansi \\
\hline 26 & C- 55 & Mushroom compost & Sonipat \\
\hline 27 & C-57 & Soil & Hisar \\
\hline 28 & C-58 & Mushroom compost & Hisar \\
\hline 29 & C-59 & Sorghum seed & Hisar \\
\hline 30 & C- 60 & Wheat grain & Hisar \\
\hline 31 & C-61 & Paper & Hisar \\
\hline 32 & $\mathrm{C}-62$ & Neem Bark & Hisar \\
\hline 33 & C- 65 & Mushroom compost & New Delhi \\
\hline 34 & C-66 & Fennel seed & New Delhi \\
\hline 35 & C-68 & Cardamom seed & New Delhi \\
\hline 36 & $\mathrm{C}-70$ & Sorghum seed & New Delhi \\
\hline 37 & $C-72$ & Sorghum seed & New Delhi \\
\hline 38 & $\mathrm{C}-73$ & Coriander seed & New Delhi \\
\hline 39 & C- 74 & Cardamom seed & New Delhi \\
\hline 40 & $C-76$ & Coriander seed & New Delhi \\
\hline 41 & C-77 & Fennel seed & New Delhi \\
\hline 42 & C- 78 & Paper & New Delhi \\
\hline 43 & C- 80 & Fennel seed & New Delhi \\
\hline 44 & C- 81 & Fenugreek seed & New Delhi \\
\hline
\end{tabular}


Table.2 Primers used for PCR amplification of different gene regions

\begin{tabular}{|c|c|c|c|c|}
\hline $\begin{array}{l}\text { Sl. } \\
\text { No }\end{array}$ & $\begin{array}{l}\text { Region for } \\
\text { amplification }\end{array}$ & Primers & Primer sequences & Reference \\
\hline \multirow[t]{2}{*}{1} & \multirow[t]{2}{*}{ Actin } & ACT-512F & 5'- ATGTGCAAGGCCGGTTTCGC-3' & \multirow{2}{*}{$\begin{array}{c}\text { Carbone and } \\
\text { Kohn, } 1999\end{array}$} \\
\hline & & $\mathrm{ACT}-783 \mathrm{R}$ & 5'- TACGAGTCCTTCTGGCCCAT-3' & \\
\hline \multirow[t]{2}{*}{2} & \multirow[t]{2}{*}{$\beta$-tubulin } & $\mathrm{Bt} 2 \mathrm{aF}$ & 5'- GGTAACCAAATCGGTGCTGCTTTC-3' & \multirow{2}{*}{$\begin{array}{c}\text { Glass and } \\
\text { Donaldson } \\
1995\end{array}$} \\
\hline & & $\mathrm{Bt} 2 \mathrm{bR}$ & 5'- AACATCAGTGTAGTGACCATTGGC-3' & \\
\hline \multirow[t]{2}{*}{3} & \multirow[t]{2}{*}{ Calmodulin } & CAL-228F & 5'- GAGTTCAAGGAGGCCTTCTCCC-3' & \multirow{2}{*}{$\begin{array}{c}\text { Carbone and } \\
\text { Kohn, } 1999\end{array}$} \\
\hline & & CAL-737R & 5'- CATCTTTCTGGCCATCATGG-3' & \\
\hline \multirow[t]{2}{*}{4} & \multirow[t]{2}{*}{$r p b 2$} & fRPB2-5F & 5'- GAYGAYMGWGATCAYTTYGG-3' & \multirow{2}{*}{$\begin{array}{l}\text { Liu et al., } \\
1999\end{array}$} \\
\hline & & fRPB2-7cR & 5'- CCCATRGCTTGYTTRCCCAT-3' & \\
\hline \multirow[t]{2}{*}{5} & \multirow[t]{2}{*}{ tef-1 } & EF1-728F & 5'- CATCGAGAAGTTCGAGAAGG-3' & \multirow{2}{*}{$\begin{array}{l}\text { Carbone and } \\
\text { Kohn, } 1999\end{array}$} \\
\hline & & EF1-928R & 5'- TACTTGGAAGGAACCCTTACC-3' & \\
\hline
\end{tabular}

\begin{tabular}{|c|c|c|c|}
\hline SI No & Isolate & ITS identification from NCBI Database & NCBI Accession number \\
\hline 1 & $\mathrm{C}-02$ & C. elatum & KT357641 \\
\hline 2 & $\mathrm{C}-\mathrm{O} 3$ & C. atrobrunneum & KT357642 \\
\hline 3 & $\mathrm{C}-05$ & C. globosum & KT357644 \\
\hline 4 & $\mathrm{C}-07$ & C. brasiliense & KT357646 \\
\hline 5 & $\mathrm{C}-08$ & C. globosum & KT357647 \\
\hline 6 & $\mathrm{C}-10$ & C. globosum & KT357648 \\
\hline 7 & $C-11$ & C. globosum & KT357649 \\
\hline 8 & $\mathrm{C}-12$ & C. funicola & KT357650 \\
\hline 9 & $\mathrm{C}-15$ & C. globosum & KT357653 \\
\hline 10 & $\mathrm{C}-16$ & C. funicola & KT357654 \\
\hline 11 & $\mathrm{C}-17$ & C.funicola & KT357655 \\
\hline 12 & $\mathrm{C}-18$ & C. atrobrunneum & KT357656 \\
\hline 13 & $\mathrm{C}-19$ & C. atrobrunneum & KT357657 \\
\hline 14 & $\mathrm{C}-20$ & C. atrobrunneum & KT357658 \\
\hline 15 & $C-21$ & C. megalocarpum & KT357659 \\
\hline 16 & $C-22$ & C. megalocarpum & KT357660 \\
\hline 17 & $C-23$ & C. megalocarpum & KT357661 \\
\hline 18 & $C-40$ & C. globosum & KT357677 \\
\hline 19 & $C-42$ & C. globosum & KT357679 \\
\hline 20 & $C-45$ & C. brasiliense & KT357682 \\
\hline 21 & $C-46$ & C. brasiliense & KT357683 \\
\hline 22 & $C-47$ & C. funicola & KT357684 \\
\hline 23 & $C-48$ & C. megalocarpum & KT357685 \\
\hline 24 & $C-50$ & C.brasiliense & KT357687 \\
\hline 25 & $C-51$ & C. globosum & KT357688 \\
\hline 26 & $C-55$ & C. globosum & KT357692 \\
\hline 27 & C-57 & C. globosum & KT357694 \\
\hline 28 & $C-58$ & C. globosum & KT371324 \\
\hline 29 & $C-59$ & C. globosum & KT371325 \\
\hline 30 & $C-60$ & C. globosum & KT371326 \\
\hline 31 & $C-61$ & C. atrobrunneum & KT371327 \\
\hline 32 & $C-62$ & C. globosum & KT371328 \\
\hline 33 & $C-65$ & C. megalocarpum & KT371330 \\
\hline 34 & $C-66$ & C. megalocarpum & KT371331 \\
\hline 35 & $C-68$ & C. atrobrunneum & KT371333 \\
\hline 36 & $C-70$ & C. megalocarpum & KT371335 \\
\hline 37 & $C-72$ & C. globosum & KT371336 \\
\hline 38 & $C-73$ & C. perlucidum & KT371337 \\
\hline 39 & $C-74$ & C. globosum & KT371338 \\
\hline 40 & $C-76$ & C. brasiliense & KT371339 \\
\hline 41 & $C-77$ & C. megalocarpum & KT371340 \\
\hline 42 & $C-78$ & C. atrobrunneum & KT371341 \\
\hline 43 & $\mathrm{C}-80$ & C. funicola & KT371343 \\
\hline 44 & $C-81$ & C. perlucidum & KT371344 \\
\hline
\end{tabular}




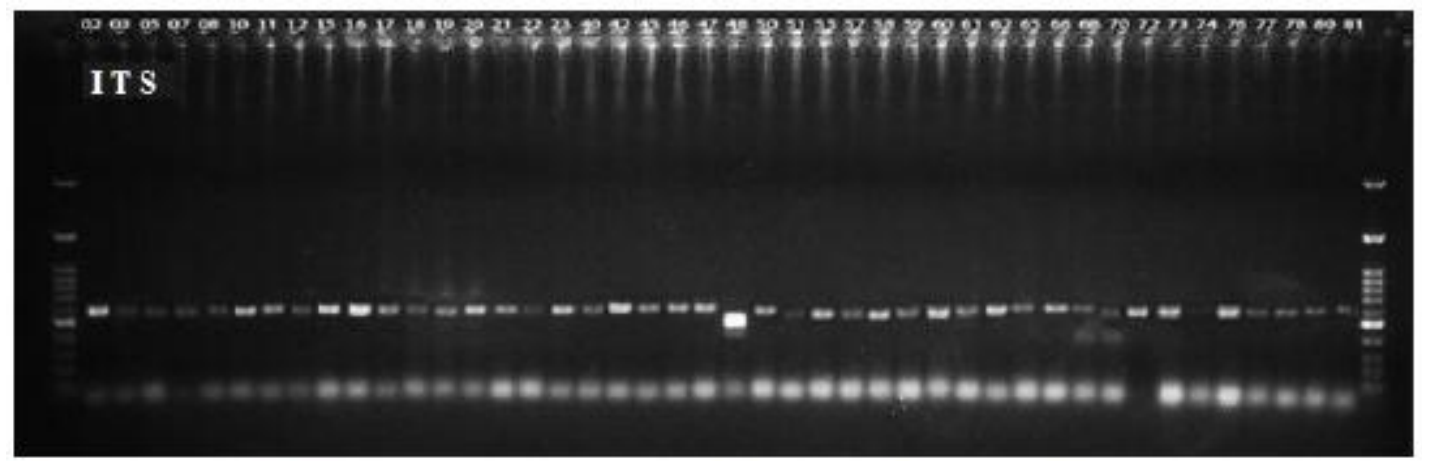

Fig 1: partial amplification of ITS region for 44 isolates of Chaetomium

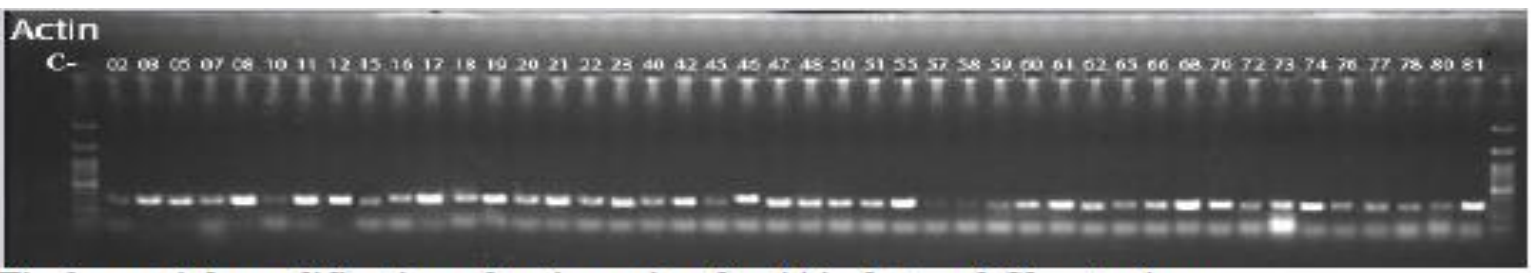

Fig 2: partial amplification of actin region for 44 isolates of Chaetomium

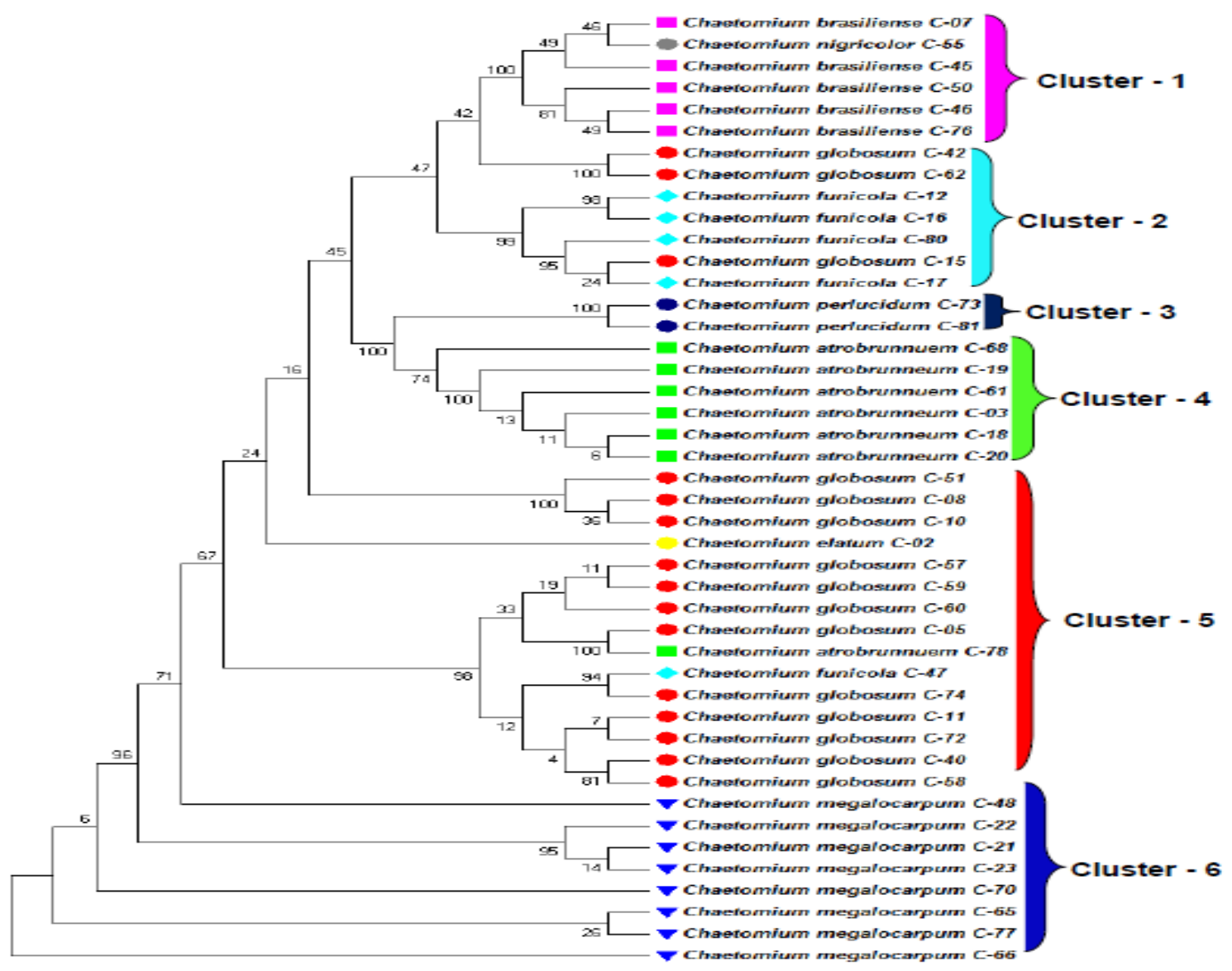

Fig 3: Phylogenetic relationship of 44 isolates of Chaetomium inferred by Actin sequences by using maximum parsimony analysis 


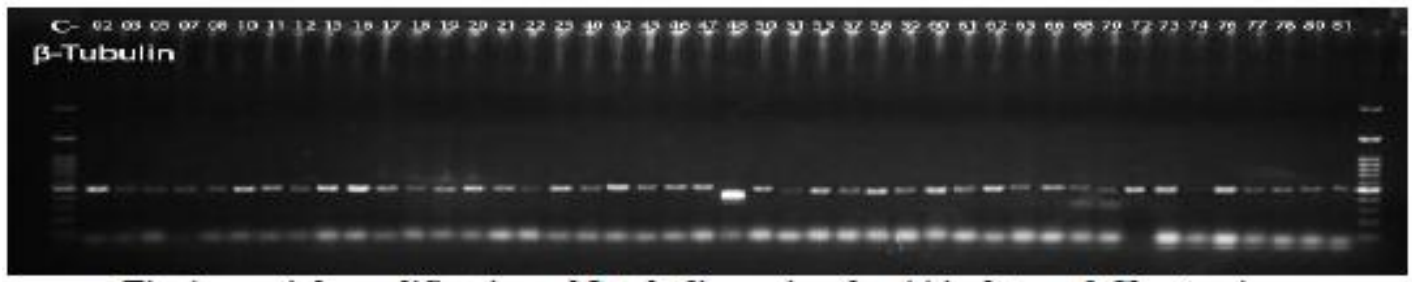

Fig 4: partial amplification of $\beta$-tubulin region for 44 isolates of Chaetomium

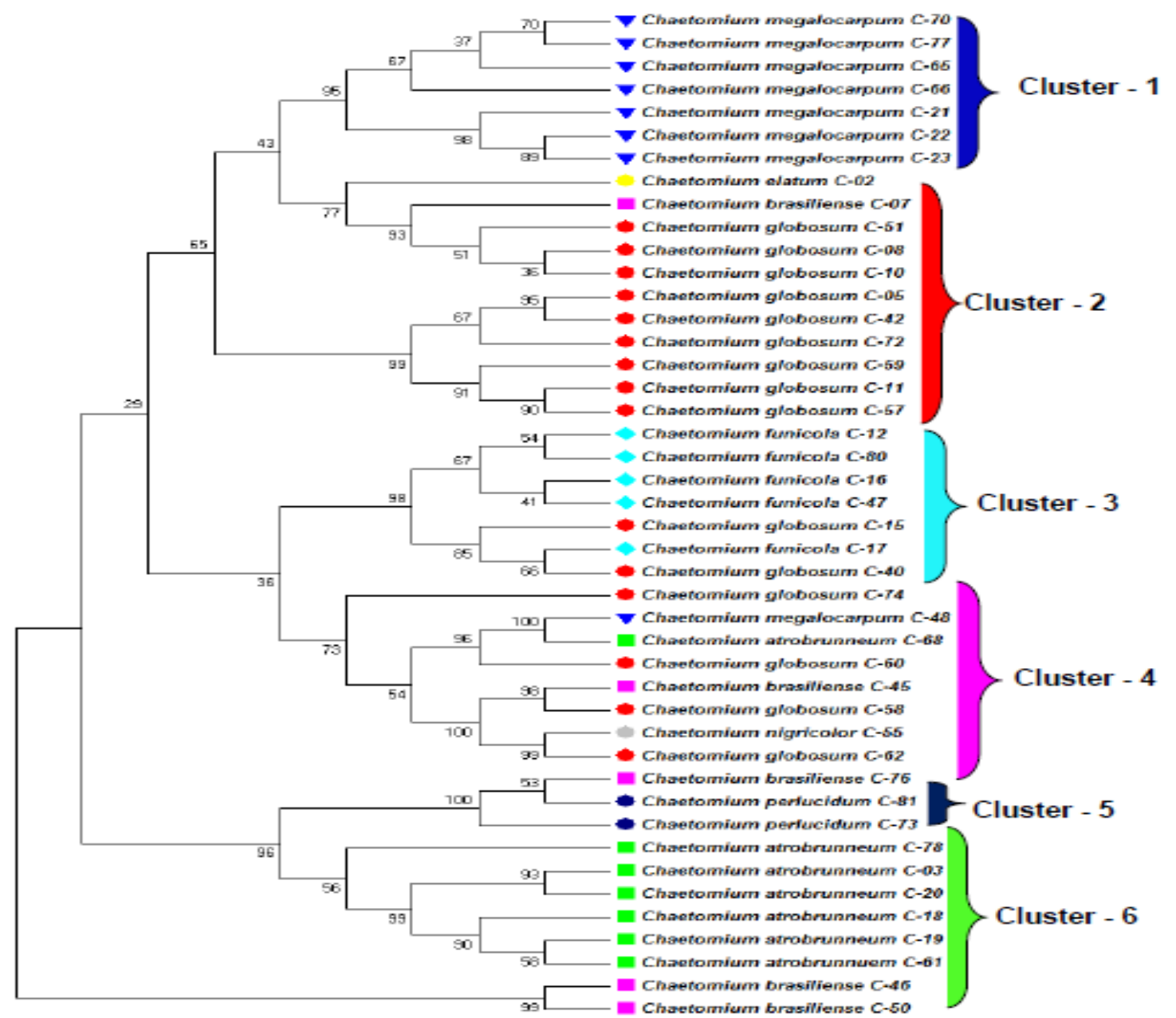

Fig 5: Phylogenetic relationship of $\mathbf{4 4}$ isolates of Chaetomium inferred by $\beta$-tubulin seauences bv using maximum parsimonv analvsis

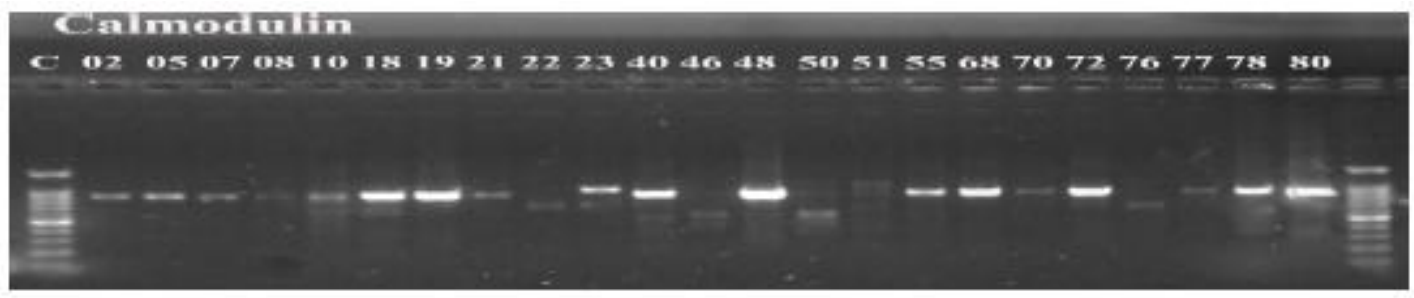

Fig 6: partial amplification of Calmodulin region for $\mathbf{2 3}$ isolates of Chaetomium 


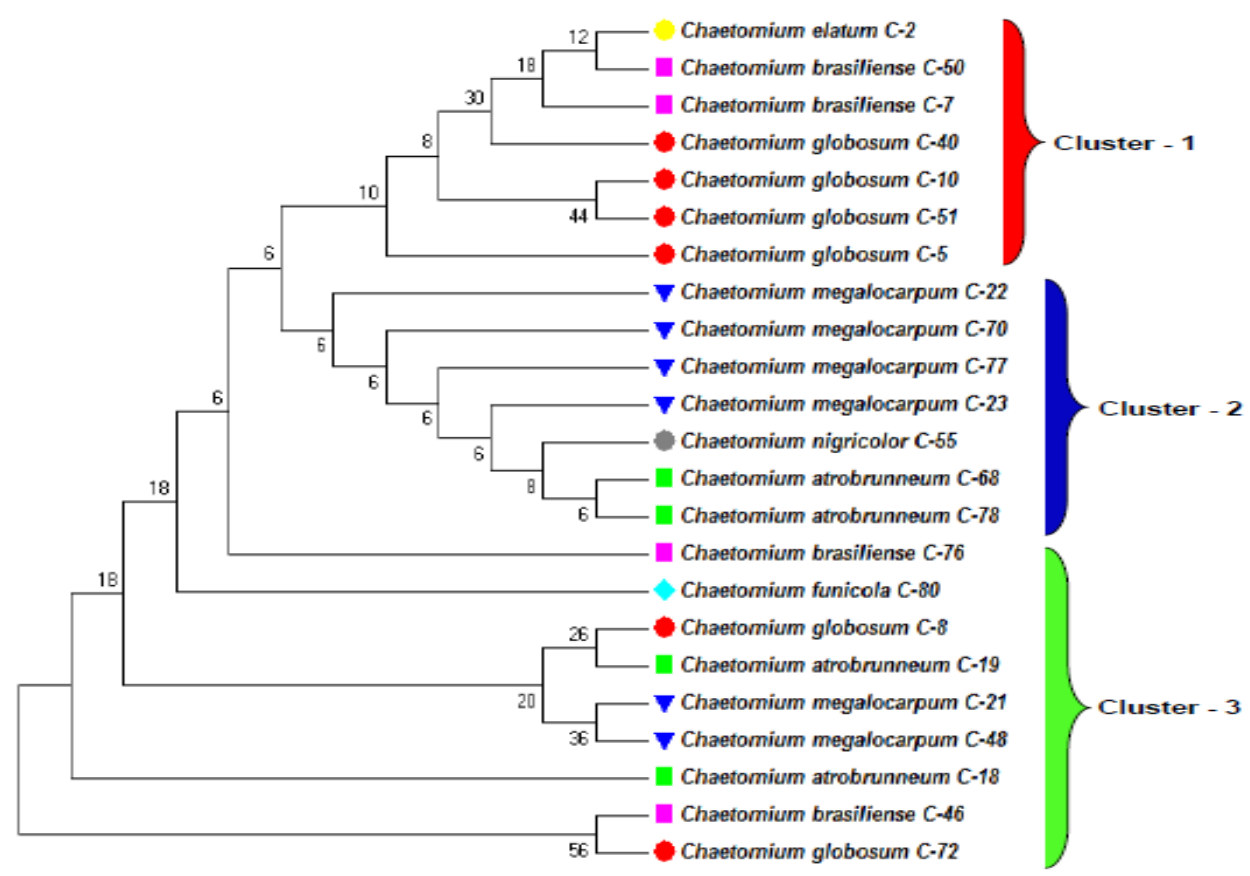

Fig 7: Phylogenetic relationship of 23 isolates of Chaetomium inferred by Calmodulin sequences by using maximum parsimony analysis

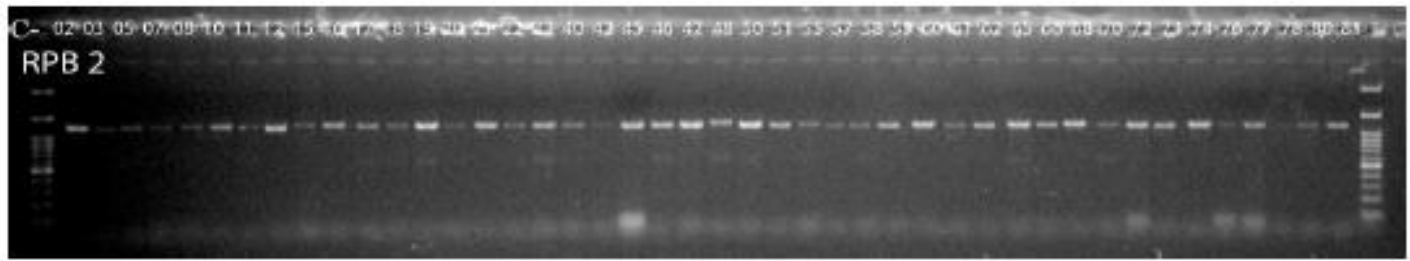

Fig.8:Amplification of $r p b 2$ gene in 44 isolates of Chaetomium

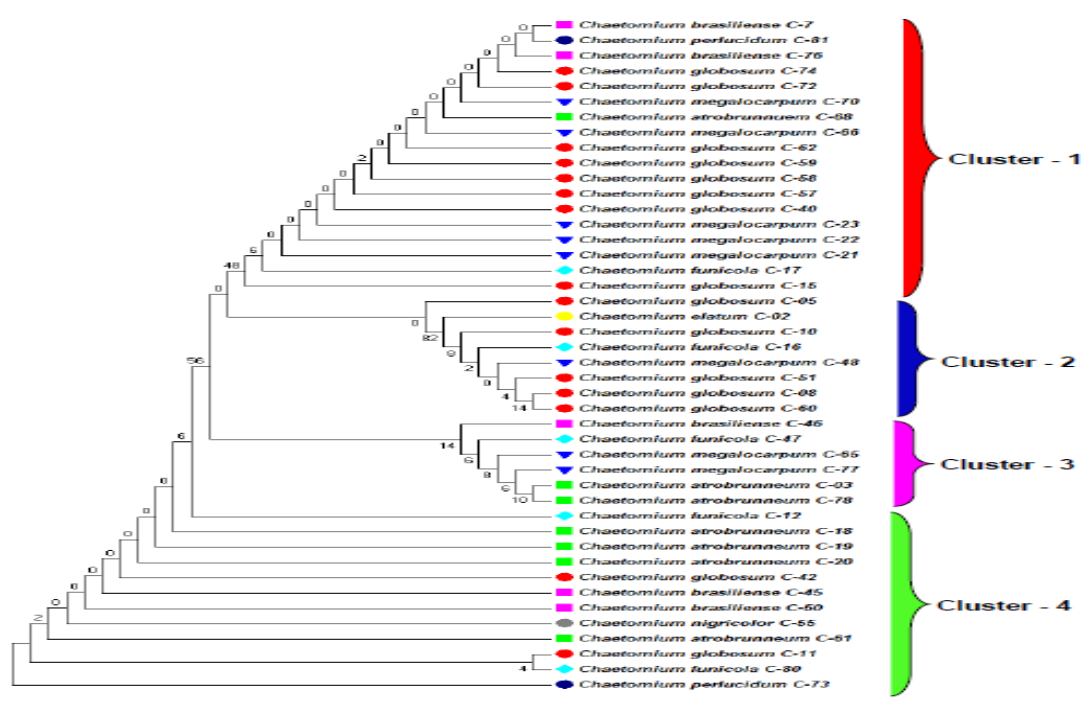

Fig 9: Phylogenetic relationship of 44 isolates of Chaetomium inferred by rpb 2 sequences by using maximum parsimony analysis 


\section{Tef- I}

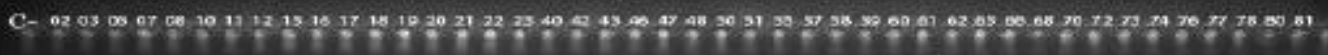

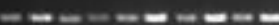

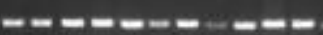

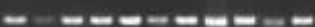

Fig 10: partial amplification of tef-1 region for $\mathbf{4 4}$ isolates of Chaetomium

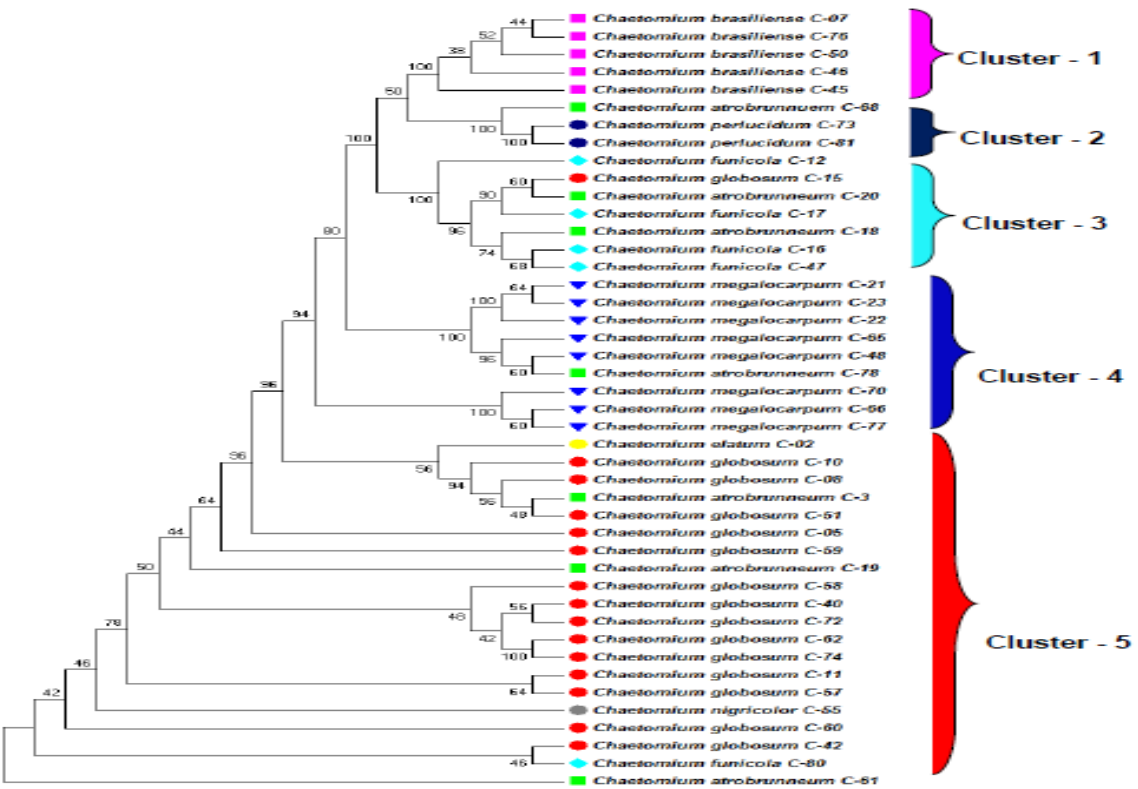

Fig 11 : Phylogenetic relationship of 44 isolates of Chaeromium inferred by tef-1 sequences by using maximum parsimony analysis

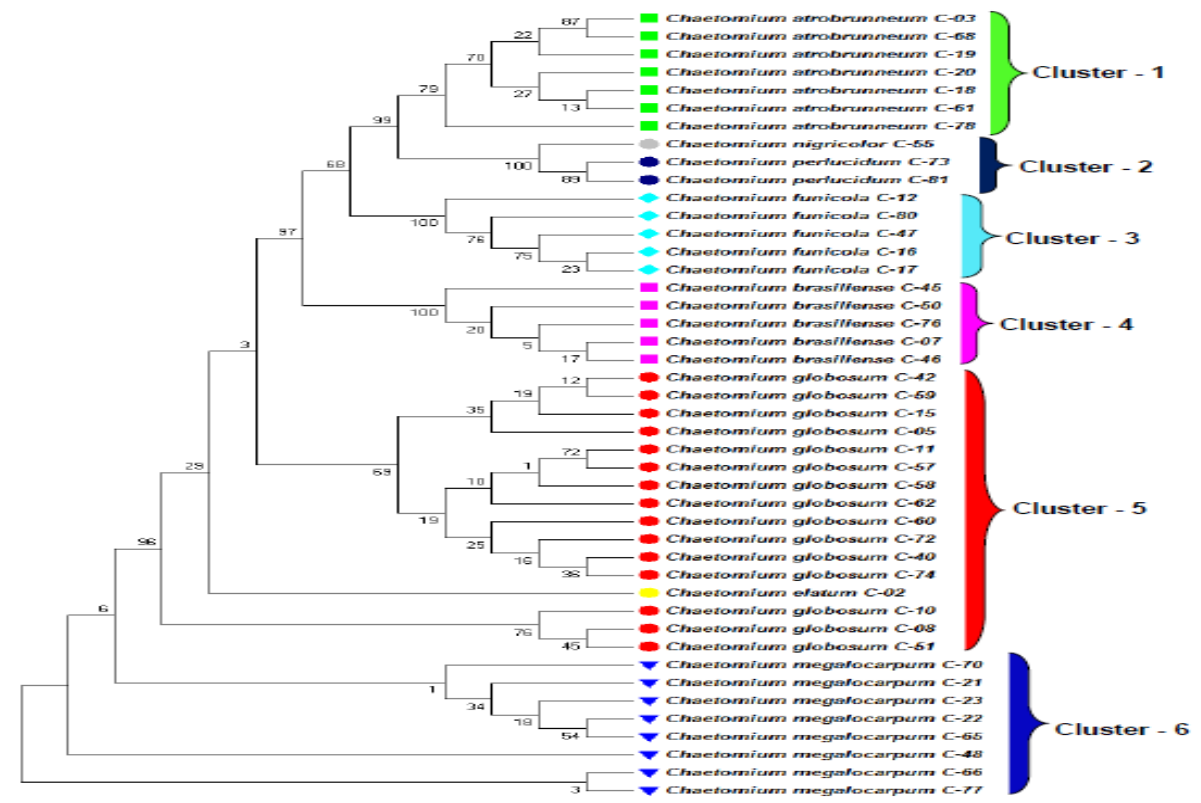

Fig 12: Phylogenetic relationship of 44 isolates of Chaetomium inferred by ITSsequences by using maximum parsimony analysis 


\section{Phylogenetic analysis of $r p b 2$ region}

It was inferred from the dendrogram (Fig. 9) that the different Chaetomium species grouped into four major clusters. Among all the regions studied for grouping the most diversified grouping was observed with this gene. In Cluster 1, the isolates of C. globsum (C-74, C-72, C-62, C-59, C-58, C-57, C-40 and $\mathrm{C}-15)$ grouped with C.brasiliense (C-07 and C-76), $C$. perlucidum (C-81), $C$. megalocarpum (C-70, C-66, C-23, C-22 and $\mathrm{C}-21), \quad$ C. atrobrunneum (C-68) and C.funicola (C-17) made a grouping. In Cluster 2, the isolates (C-05, C-10, C-51, C-08 and C60) of C. globosum were grouped with one isolate of each C. elatum (C-02), C. funicola (C-16) and C. megalocarpum (C-48). In the six member Cluster no.3, two isolates of $C$. megalocarpum (C-65 and C-77), two isolates of $C$. atrobrunneum (C-03 and $\mathrm{C}-78$ ), one isolate of $C$. brasiliense (C-46) and one isolate of C. funicola (C-47) were found together. One isolate of C. funicola (C-12), three isolates of C. atrobrunneum (C-18, C19, C-20 and C-61), two isolates of C. globosum (C-42 and C-11), two isolates of $C$. brasiliense (C-45 and C-50), one isolate of $C$. nigricolor (C-55) and one isolate of $C$. perlucidum (C-73) were present in Cluster 4.

\section{Phylogenetic analysis of tef-1 region}

The phylogenetic grouping using tef- 1 sequences is depicted in Figure 11. Different Chaetomium species were grouped into five major clusters. All the isolates of $C$. brasiliense (C-07, C-76, C-50, C-46 and C45) were grouped in Cluster 1 . In the Cluster 4 all the isolates of C. megalocarpum (C-21, C-23, C-22, C-65, C-48, C-70, C-66 and C77) were grouped along with one isolate of $C$. atrobrunneum (C-78). The isolates of $C$. perlucidum viz., C-73 and C-81 with one isolate of $C$. atrobrunneum (C-68) grouped in Cluster 2. In Cluster 3 along with isolates of
C. funicola viz., C-12, C-17, C-16, and C-47 two isolates (C-20 and C-18) of $C$. atrobrunneum and one isolate (C-15) of $C$. globosum grouped together. In Cluster 5 all the isolates of $C$. globosum (C-10,C-08,C51,C-05,C-59,C-58,C-40,C-72,C-62,C-74,C$11, \mathrm{C}-57, \mathrm{C}-60$ and C-42) were found together along with isolates of other species viz., $C$. elatum (C-02), C. atrobrunneum (C-3,C-19 and C-61), C. nigricolor (C-55) and $C$. funicola (C-80).

\section{Phylogenetic analysis of ITS region}

Most accurate grouping was obtained through ITS region sequences wherein Chaetomium species isolates were grouped into six major clusters as depicted in Fig. 12.Seven isolates of C. atrobrunneum (C-03, C-68, C-19, C-20, $\mathrm{C}-18, \mathrm{C}-61$ and C-78), five isolates of $C$. funicola (C-12, C-80, C-47, C-16 and C-17), five isolates of $C$. brasiliense (C-45, C-50, C76,C-07 and C-46) and eight isolates of $C$. megalocarpum (C-70, C-21, C-23, C-22, C65, C-48, C-66 and C-77) made into separate Clusters, Cluster 1, 3, 4 and 6 respectively., C. nigricolor (C-55) and C. perlucidum (C-73 and C-81) were found together in Cluster 2. Fifteen isolates of C. globosum (C-42, C-59, C-15, C-05, C-11, C-57, C-58, C-62, C-60, C72, C-40, C-74, C-10, C-08 and C-51) in Cluster 5 made into a single group with one isolate of C. elatum (C-02).

All the species of Chaetomium (C. globosum, C. atrobrunneum, C. brasiliense, C. elatum, C. cochliodes, C. funicola, C. nigicolor, $C$. megalocarpum and $C$. perlucidum) which were authentically identified using ITS region were further analyzed for Phylogenetic grouping. Forty four isolates of Chaetomium were subjected to PCR amplification of genes viz., actin, $\beta$-tubulin, calmodulin, $r p b 2$ and tef-1. Sequences of these regions were subjected to maximum parsimony phylogenetic analysis. The clustering obtained 
was compared with ITS based clustering. In the present study ITS region gave best grouping for the Chaetomium species through phylogeny. The clustering of different species through ITS sequences matched with the earlier findings of Aggarwal et al., (2013) in which ITS sequence data could clearly differentiate 18 different isolates of the Chaetomium spp. collected from different specialized life strategies surviving in diverse climates. Wang et al., (2014) reported the multigene phylogenetic analyses with ribosomal ITS, partial ribosomal large subunits (28S rDNA), $\beta$-tubulin, the translation elongation factor $1 \alpha(\mathrm{TEF} 1-\alpha)$, and the largest subunit of RNA polymerase II (rpbl) and recognized eight well-supported lineages within the monophyletic $C$. indicum group using ITS sequences. All these data sufficiently supplements the grouping of species of Chaetomium by using ITS sequences for phylogenetic analysis.

ITS gene region was the best region for Chaetomium species identification using NCBI database. ITS also found to be best region for the grouping of the Chaetomium species through phylogenetic tree.

\section{Acknowledgements}

The authors thank the Head, Division of Plant Pathology, Indian Agricultural Research Institute, New Delhi for the help in various aspects of this study.

\section{References}

Aggarwal, R., Kharbikar, L. L., Sharma, S., Gupta, S. and Yadav, A. (2013).Phylogenetic relationships of Chaetomium isolates based on the internal transcribed spacer region of the rRNA gene cluster. Afr J Biotechnol.12 (9): $914 \quad-\quad 920 . \quad$ DOI: 10.5897/AJB12.2633.
Aggarwal, R., Tiwari, A. K., Srivastava. K. D. and Singh, D. V. (2004). Role of antibiosis in the biological control of spot blotch (Cochliobolus sativus) of wheat by Chaetomium globosum. Mycopathologia. 157: 369-377. DOI: 10.1023/B:MYCO.0000030446.86370.1 4.

Asgari, B. and Zare, R., (2011). The genus Chaetomium in Iran, a phylogenetic study including six new species. Mycologia. 103(4): 863-82.DOI: 10.3852/10-349.

Balazy, S., Wrzosek, M., Sosnowska, D., Tkaczuk, C. and Muszewska, A. (2008). Laboratory trials to infect insects and nematodes by some acaropathogenic Hirsutella strains (Mycota: Clavicipitaceous anamorphs). J Invertebr Pathol., 97: 103 - 113. https://doi.org/10.1016/j.jip.2007.08.00 6.

Carbone, I. and Kohn, L. M. (1999). A method for designing primer sets for speciation studies in filamentous ascomycetes. Mycologia., 91: 553 - 556. DOI: $10.2307 / 3761358$.

Culling, K. W. (1992). Design and testing of plant specific PCR primer for ecological evolutionary studies. Mol Ecol.1: 233240.

DOI: $10.1111 / \mathrm{j} .1365-$ 294X.1992.tb00182.x.

Dhingra, O.D., Mizubuti, E.S.G. and Santana, F.M. (2003). Chaetomium globosum for reducing primary inoculum of Diaporthe phaseolorum f. $\mathrm{sp}$. meridionalis in soil surface soybean stubble in field conditions. Biological Control. 26: 302-310. https://doi.org/ 10.1016/S1049-9644(02)00167-6.

Felsenstein J. (1985). Confidence limits on phylogenies: An approach using the bootstrap. Evol. 39:783-791. DOI: 10.2307/2408678.

Glass, N. L. and Donaldson, G. C. (1995). Development of primer sets designed 
for use with the PCR to amplify conserved genes from filamentous ascomycetes. Appl Environ Microbiol., 61: $1323 \quad-1330$. https://www.ncbi.nlm.nih.gov/pubmed/ 7747954.

Liu, Y. J., Whelen, S. and Hall, B. D. (1999). Phylogenetic relationships among Ascomycetes: Evidence from an RNA Polymerse II Subunit. Mol Biol Evol., 16 (12): 1799 - 1808. https://www.ncbi.nlm.nih.gov/pubmed/ 10605121.

Nei M. and Kumar S. (2000). Molecular Evolution and Phylogenetics. Oxford University Press, New York.

Santamaria, M., Vicario, S.,Pappadà, G.,Scioscia, G., Scazzocchio C. and Saccone,C. (2009). Towards barcode markers in Fungi: an intron map of Ascomycota mitochondria. BMC Bioinformatics. 10(6):S15. DOI: 10.1186/1471-2105-10-S6-S15.

Sharma, R., Kulkarni, G., Sonawane, M. S. and. Shouche, Y. S. (2013). A new endophytic species of Chaetomium from Jatropha podagrica.Mycotaxon.124. 117-126. DOI: $10.5248 / 124.117$.

Soytong, K., Kanokmedhakul, S., Kukongviriyapa, V. and Isobe, M. (2001). Application of Chaetomium species (Ketomium ${ }^{\circledR}$ ) as a new broad spectrum biological fungicide for plant disease control: A review article. Fungal Diversity. 7: 1-15.
Umikalsom, M.S., Ariff, A.B., Hassan, M.A. and Karim, M.I.A. (1998). Kinetics of cellulose production by Chaetomium globosum at different levels of dissolved oxygen tension using oil palm empty fruit bunch fibre as substrate. Worl J Microbiol. Biotechnol. 14(4): 491-498. DOI: $\quad 10.1023 / \mathrm{A}$ : 1008871528360.

Umikalsom, M.S., Ariff, A.B., Shamsuddin, Z.H., Tong, C. C., Hassan, M. A. and Karim, M.I.A. (1997). Production of cellulase by a wild strain of Chaetomium globosum using delignified oil palm empty-fruit-bunch fibre as substrate. App Microbiol Biotechnol. 47(5): 590-595. DOI: 10.1007/s002530050978.

Wang, X. W., Lombard, L., Groenewald, Z. J., Li, J., Vidiera, S. I. R., Samson, A. R., Liu, Z. X. and Crous, W. P., (2016) Phylogenetic reassessment of the Chaetomium globosum species complex. Persoonia. 36: 83 - 133. doi: 10.3767/003158516X689657.

Wang, X. W., Wang, X., Liu, F., Zhao, X., Li, J. and Cai, L. (2014). Phylogenetic assessment of Chaetomium indicum and allied species, with the introduction of three new species and epitypification of C. funicola and C. indicum. Mycol Progress., 13: 719 - 732.DOI: 10.1007/s11557-013-0955-x.

\section{How to cite this article:}

Chandra Sekhar, V., T. Prameeladevi, Deeba Kamil and Dama Ram. 2018. Studies on Phylogeny of Chaetomium Species of India. Int.J.Curr.Microbiol.App.Sci. 7(08): 3154-3166. doi: https://doi.org/10.20546/ijcmas.2018.708.337 